\title{
Salinity-induced mixed and barrier layers in the southwestern tropical Atlantic Ocean off the northeast of Brazil
}

\author{
M. Araujo ${ }^{1, *}$, C. Limongi ${ }^{1, *}$, J. Servain ${ }^{2,3,{ }^{*}}$, M. Silva ${ }^{1,{ }^{*}}$, F. S. Leite ${ }^{1}$, D. Veleda ${ }^{1}$, and C. A. D. Lentini ${ }^{4, *}$ \\ ${ }^{1}$ Departamento de Oceanografia, Universidade Federal de Pernambuco, Recife-PE, Brazil \\ ${ }^{2}$ Institut de Recherche pour le Développement (IRD), UMR-182, Paris, France \\ ${ }^{3}$ Visiting Scientist at Fundação Cearense de Meteorologia e Recursos Hídricos (FUNCEME), Fortaleza, CE, Brazil \\ ${ }^{4}$ Departamento de Física da Terra e do Meio Ambiente, Universidade Federal da Bahia, Salvador-BA, Brazil \\ *GOAT - Grupo de Oceanografia Tropical - http://www.goat.fis.ufba.br
}

Received: 15 January 2009 - Published in Ocean Sci. Discuss.: 9 March 2009

Revised: 13 January 2011 - Accepted: 14 January 2011 - Published: 20 January 2011

\begin{abstract}
High-resolution hydrographic observations of temperature and salinity are used to analyze the formation and distribution of isothermal depth $\left(Z_{\mathrm{T}}\right)$, mixed depth $\left(Z_{\mathrm{M}}\right)$ and barrier layer thickness (BLT) in a section of the southwestern Atlantic $\left(0^{\circ} 30^{\prime} \mathrm{N}-14^{\circ} 00^{\prime} \mathrm{S} ; 31^{\circ} 24^{\prime}-41^{\circ} 48^{\prime} \mathrm{W}\right)$, adjacent to the northeastern Brazilian coast. Analyzed data consists of 279 CTD casts acquired during two cruises under the Brazilian REVIZEE Program. One occurred in late austral winter (August-October 1995) and another in austral summer (January-April 1997). Oceanic observations are compared to numerical modeling results obtained from the French Mercator-Coriolis Program. Results indicate that the intrusion of subtropical Salinity Maximum Waters (SMW) is the major process contributing to the seasonal barrier layer formation. These waters are brought by the South Equatorial Current (SEC), from the subtropical region, into the western tropical Atlantic boundary. During late austral winter southeastern trade winds are more intense and ITCZ precipitations induce lower surface salinity values near the equator. During this period a $5-90 \mathrm{~m}$ thick BLT (median $=15 \mathrm{~m}$ ) is observed and BLT $>30 \mathrm{~m}$ is restricted to latitudes higher than $8^{\circ} \mathrm{S}$, where the intrusion of salty waters between $8^{\circ}-12.3^{\circ} \mathrm{S}$ creates shallow mixed layers over deep $\left(Z_{\mathrm{T}} \geq 90 \mathrm{~m}\right)$ isothermal layers. During austral summer, shallow isothermal and mixed layers prevail, when northeasterly winds are predominant and evaporation overcomes precipitation, causing saltier waters at the surface/subsurface layers. During that period observed BLT varies from 5 to $70 \mathrm{~m}$ and presents thicker me-
\end{abstract}

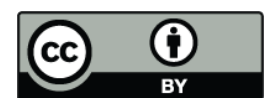

Correspondence to: M. Araujo (moa@ufpe.br) dian value of $35 \mathrm{~m}$, when comparing to the winter. Furthermore, BLT $\geq 30 \mathrm{~m}$ is observed not only in the southernmost part of the study area, as verified during late winter, but in the latitude range $2^{\circ}-14^{\circ} \mathrm{S}$, where near-surface salty waters are transported westward by the SEC flow. These results indicate that the inclusion of salinity dynamics and its variability are necessary for studying mixed and barrier layer behaviors in the tropical Atlantic, where ocean-atmosphere coupling is known to be stronger.

\section{Introduction}

The southwestern tropical Atlantic Ocean is a region of prime importance to global climate change. It is an area through which oceanic signals, from intra-seasonal to decadal scales, must pass (Dengler et al., 2004; Schott et al., 2005). Moreover, this region is subjected to cyclonic and anticyclonic gyres strongly controlled by surface winds (Stramma and Schott, 1999; Lumpkin and Garzoli, 2005). These gyres drive the divergence of the southern pathway of the South Equatorial Current (sSEC) (Rodrigues et al., 2007; Silva et al., 2009), which is partially at the birth site of several current systems that flow along the Brazilian coastline. The northern branch of the sSEC termination flows northward, forming the North Brazil Current/North Brazil Undercurrent (NBC/NBUC) system. This powerful western boundary current contributes to the northward Guyana Current (Bourlès et al., 1999; Stramma et al., 2005) and to the eastward North Equatorial Counter Current (NECC). It also feeds its associated complex retroflection system (Goes et al., 2005), as well as the eastward Equatorial Undercurrent (EUC). It is believed

Published by Copernicus Publications on behalf of the European Geosciences Union. 
that NBC accounts for approximately one-third of the net warm-water flow transported across the equatorial tropical gyre boundary into the North Atlantic; this partially compensates for the southward export of North Atlantic Deep Water (NADW) (Dengler et al., 2004; Schott et al., 2005). The southern branch of sSEC forms the Brazil Current (BC), which flows poleward along the Brazilian coast.

Offshore, the upper ocean density stratification is primarily controlled by temperature variations in the thermocline depth. However, there is some evidence that salinity variations can regulate the mixed layer (e.g., Sprintall and Tomczak, 1992). The occurrence of the isohaline layer being shallower than the isothermal layer in the tropical ocean has been studied since the Meteor research cruises in 1936 (Defant, 1961). The barrier layer (BL), which is a layer between the halocline and the thermocline (Lukas and Lindström, 1991), may isolate the upper isohaline layer from the cold thermocline waters, thereby affecting the ocean heat budget and its exchanges with the atmosphere (Swenson and Hansen, 1999; Pailler et al., 1999; Foltz and McPhaden, 2009). Heavy precipitation in the western portion of a tropical ocean basin is the main mechanism accounting for BL formation (e.g., Sprintall and Tomczak, 1992; Ando and McPhaden, 1997; Tanguy et al., 2010). When the BL occurs, the energy transferred from the atmosphere to the ocean, by wind and buoyancy forcing, may get trapped in the upper mixed layer, limited by the salinity stratification (e.g., Delcroix and McPhaden, 2002). This stratification is thinner, and theoretically more reactive, than the one defined by the temperature mixed layer (Vialard and Delecluse, 1998; De Boyer Montégut et al., 2007).

In the western Pacific, the thick climatologically important BL is due to the eastward fresh jets flowing over subducted salty waters (Vialard and Delecluse, 1998). Cronin and McPhaden (2002) analyzed BL responses to westerly wind gusts over the tropical Atmosphere Ocean (TAO) array in the equatorial Pacific, and they discussed the main mechanisms by which BLs may form and spread. General charts of the seasonal variability of BL thickness in tropical oceans were obtained using Levitus climatological data (Levitus, 1982). These charts were used to determine the extent of the influence of salinity in the depth of the mixed layer (Sprintall and Tomczak, 1992). More recently, De Boyer Montégut et al. (2007) and Mignot et al. (2007) used instantaneous T/S profiles, including Argo data, to construct global ocean climatology of monthly mean properties of the BL phenomenon. In the western tropical Atlantic, these charts suggest that the subduction of subtropical salty surface waters toward the equator during winter, and their advection by the equatorial current system, might be the mechanism that forms the BL. This hypothesis is partially supported by the presence of subsurface Salinity Maximum Waters (SMW), as called by Defant (1936), along the western Atlantic boundary (Pailler et al., 1999; Stramma et al., 2005; Silva et al., 2005). These authors argue that this salty water, which is formed in the South Atlantic subtropical gyre, enters the region within the NBUC that flows northwestward along the Brazilian continental slope. The SMW is also known as Subtropical Underwater (Lambert and Sturges, 1977), which is characterized by a salinity maximum at about $100 \mathrm{~m}$ depth, at densities slightly below $\sigma_{\theta}=25.0$.

As stated above, numerous studies about BLs have been reported in the literature for western equatorial Pacific and Indian Oceans (e.g., Sprintall and Tomczak, 1992; Delcroix and McPhaden, 2002). However, little has been done to identify formation of salinity-induced BLs at the southwestern boundary of the tropical Atlantic. This is the main topic of the present study. Our investigation is based on the analysis of hydrographic vertical profiles obtained under the Brazilian REVIZEE Program (Medeiros et al., 2009a, b) off the Northeast of Brazil. The paper is outlined as follows: data and methods are delineated in Sect. 2, where the area of study is presented along with the criteria used for determining the isothermal, mixed and barrier layers; results are presented in Sect. 3; this is followed by a summary and conclusions in Sect. 4.

\section{Data and methodology}

\subsection{Data collection and numerical results}

The area of study comprised a section of the western tropical Atlantic $\left(0^{\circ} 30^{\prime} \mathrm{N}-14^{\circ} 00^{\prime} \mathrm{S} ; 31^{\circ} 24^{\prime}-41^{\circ} 48^{\prime} \mathrm{W}\right)$, adjacent to the Brazilian NE coast (Fig. 1). High-resolution Conductivity, Temperature, Depth (CTD) hydrographic data were collected onboard the R/V Antares under the REVIZEE Program (Brazilian Program for Assessing the Sustainable Potential of the Live Resources of the Exclusive Economic Zone). The dataset gathered during this program (Medeiros et al., 2009a, b) comprised 279 continuous CTD casts -146 were obtained during the late austral winter (2 August 199526 October 1995) and 133 during the austral summer (20 January 1997-17 April 1997).

Vertical and continuous profiles of temperature and salinity were obtained using a Sea Bird Electronics SBE911plus CTD probe. It was equipped with a centrifugal pump and high-resolution sensors for conductivity, temperature and pressure measurements. During all of the cruises, the CTD was operated at up to a depth of around $500 \mathrm{~m}$, with a descending speed of $1 \mathrm{~m} \mathrm{~s}^{-1}$ and a sampling frequency of $24 \mathrm{~Hz}$. The equipment was connected to an SBE 11plus boarding platform during the profiling, which permitted realtime monitoring of data acquisition and quality control.

Oceanic observations were compared to numerical modeling results obtained from the French Mercator-Coriolis Program (http://www.mercator-ocean.fr). The numerical product used herein (PSY3V2) is the result of the global ocean model OPA (ORCA025 configuration) with $1 / 4^{\circ}$ of horizontal resolution and 50 levels of vertical grid. It is refined at 


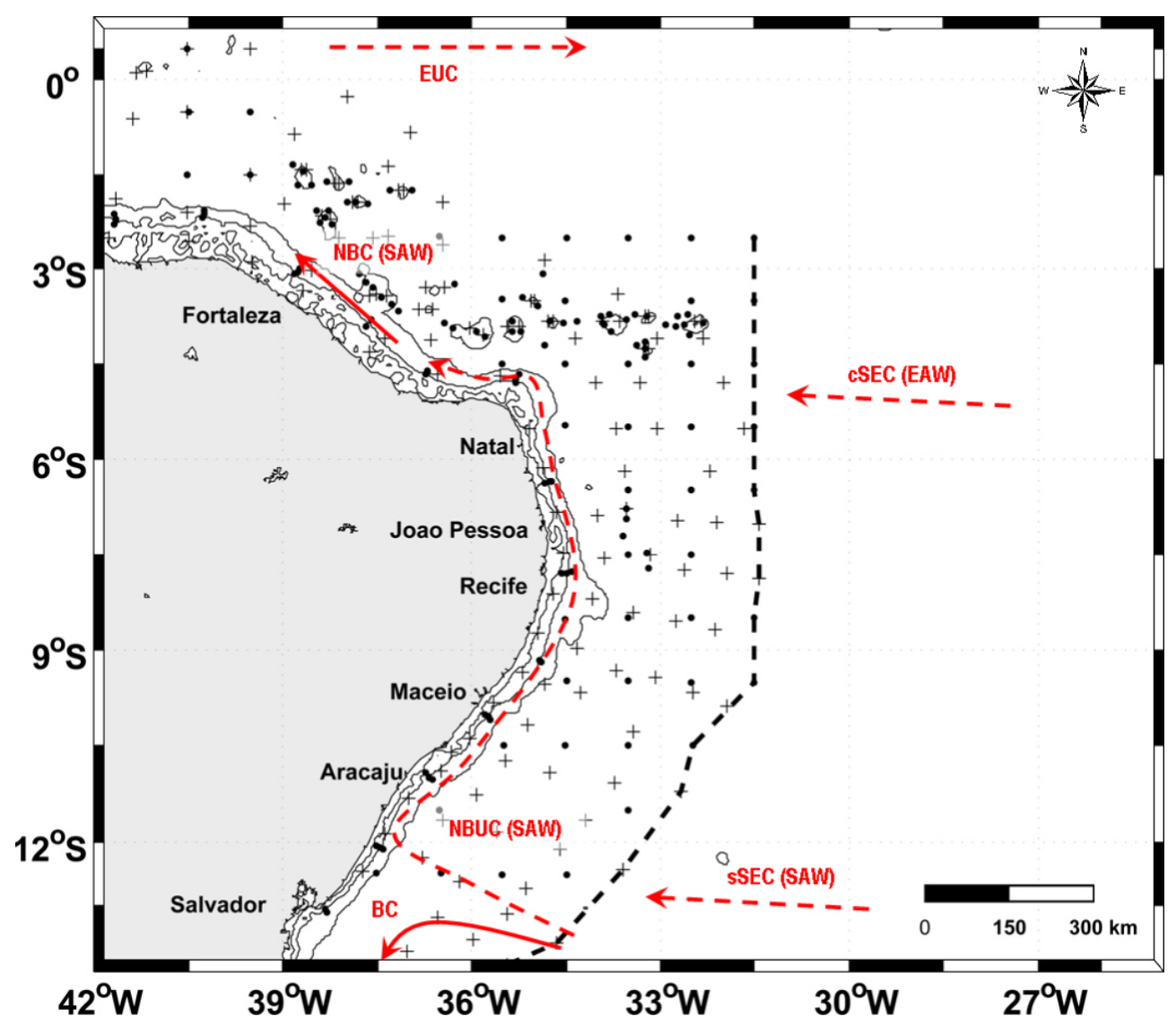

Fig. 1. Area of study with indication of the $20 \mathrm{~m}, 100 \mathrm{~m}$ and $2000 \mathrm{~m}$ isobaths. (a) Dots and crosses indicate, respectively, CTD stations during late austral winter (August-October 1995) and austral summer (January-April 1997). Black dashed lines indicate the limited area along which salinity and water mass origins were investigated (T/S diagrams). The schematic surface (subsurface) currents are represented in red solid (dashed) arrows: $\mathrm{NBC}=$ North Brazil Current; EUC $=$ Equatorial Undercurrent; NBUC $=$ North Brazil Undercurrent; $\mathrm{c} / \mathrm{sSEC}=$ central/southern branch of the South Equatorial Current; $\mathrm{BC}=$ Brazil Current.

the surface with a discretization of $1 \mathrm{~m}$ up to $20 \mathrm{~m}$ depth, and ending in the bottom of the ocean with $500 \mathrm{~m}$ layer steps. Atmospheric forcing derived from ECMWF (European Centre for Medium-Range Weather Forecasts) with precipitation coming from GPCP (Global Precipitation Climatology Project) data set. The simulation used here was run during the 1992-2006 period.

\subsection{Criteria for determining isothermal, mixed and barrier layers}

Barrier layer thickness (BLT) is calculated as a difference between mixed $\left(Z_{\mathrm{M}}\right)$ and isothermal $\left(Z_{\mathrm{T}}\right)$ layers $\left(\mathrm{BLT}=Z_{\mathrm{M}}-\right.$ $Z_{\mathrm{T}}$ ). The definitions for determining $Z_{\mathrm{M}}$ and $Z_{\mathrm{T}}$ are arbitrary, and different parameters can be used as criteria. For example, Brainerd and Gregg (1995) based their criteria on a difference in temperature $T$ (or density, $\sigma_{t}$ ) from the surface value. For evaluating $Z_{\mathrm{T}}$, deviations varying from $0.1{ }^{\circ} \mathrm{C}$ to $1.0^{\circ} \mathrm{C}$ from sea surface temperatures are normally considered (Monterrey and Levitus, 1997; Kara et al., 2000;
De Boyer Montégut et al., 2004). $Z_{M}$ is estimated as the depth at which density is equal to its sea surface value, plus an increment $\Delta \sigma_{t}$, which is equivalent to a desired net decrease in temperature. Spall (1991), for example, uses $\Delta \sigma_{t}=0.125 \sigma_{t}(0)$ for determining the mixed layer depth, while Sprintall and Tomczak (1992), as well as Ohlmann et al. (1996), adopt $\Delta \sigma_{t}=0.5^{\circ} \mathrm{C}\left(\partial \sigma_{t} / \partial T\right)$, where $\partial \sigma_{t} / \partial T$ is the coefficient of thermal expansion.

The criteria used in this paper for determining isothermal and mixed layers are the same as those defined by Sprintall and Tomczak (1992). These authors considered that the depths of the isothermal and mixed layers are evaluated in terms of temperature and density steps $-\Delta T=0.5^{\circ} \mathrm{C}$ and $\Delta \sigma_{t}=0.5^{\circ} \mathrm{C}\left(\partial \sigma_{t} / \partial T\right)-$ from the sea surface temperature and density $\left(T(0)\right.$ and $\left.\sigma_{t}(0)\right)$ obtained from CTD vertical profiles:

$$
\begin{aligned}
& Z_{\mathrm{T}}=z(T=T(0)-\Delta T) \\
& Z_{\mathrm{M}}=z\left(\sigma_{t}=\sigma_{t}(0)+\frac{\partial \sigma_{t}}{\partial T} \Delta T\right)
\end{aligned}
$$


where $\partial \sigma_{t} / \partial T$ is calculated as a function of the surface temperature and salinity (Blanck, 1999). Since the SBE911plus CTD has two thermometers, with an accuracy of about $0.001{ }^{\circ} \mathrm{C}$, the error in computing $Z_{\mathrm{T}}$ for a $\Delta T=0.5^{\circ} \mathrm{C}$ is around $0.2 \%$ for a local $Z_{\mathrm{T}}$. Moreover, previous studies in the western tropical Atlantic also used the $0.5^{\circ} \mathrm{C}$ criterion for the isothermal layer and its equivalent in density change (Silva et al., 2005), whose are found to be the most adaptable due to their robustness (Tanguy et al., 2010).

When density stratification is exclusively controlled by temperature, the isothermal layer depth becomes equivalent to the mixed layer depth, and $\mathrm{BLT}=0$. A particular situation occurs when the near-surface distribution of salinity is sufficiently strong enough to induce a pycnocline inside of the isothermal layer, or $Z_{\mathrm{M}}<Z_{\mathrm{T}}$. In such a case, BLT $>0$ and warm surface waters may be maintained in isolation from cool thermocline waters.

As in De Boyer Montégut et al. (2007), and Mignot et al. (2007), an analysis of individual T/S profiles, combined with a kriging interpolation (within a radius of $400 \mathrm{~km}$ with at least 5 grid points), is used to construct isothermal, mixed and barrier layers charts.

\section{Mixed and barrier layers in the southwestern tropical Atlantic}

\subsection{Water masses}

Wilson et al. (1994) and Bourlès et al. (1999) identified three different origins for the water masses at the upper western equatorial Atlantic: North Atlantic Water (NAW), South Atlantic Water (SAW), and Eastern tropical Atlantic Water (EAW). The NAW originates in the subtropical region of the northern hemisphere and is advected towards the equator by the North Equatorial Current (NEC). This water mass is mostly characterized by high salinity values and relatively low dissolved oxygen $\left(\mathrm{O}_{2}\right)$ concentrations below the thermocline. The SAW exhibits high salinity values above the thermocline, as well as low salinity values and high $\mathrm{O}_{2}$ concentrations below it, in relation to the NAW. It is advected to the study region through subduction processes from subtropical areas by the southern branch of the SEC. The EAW reaches the area of interest via the southern edge of the NEC, along with the central and northern branches of the SEC. This EAW is characterized by the lowest concentrations of oxygen and salinity around the thermocline, when compared to the SAW.

The origin of the water masses entering the area of study is identified using T/S diagrams of the easternmost boundary hydrographic stations (Fig. 1). The T/S references used to identify the water masses were obtained from Wilson et al. (1994) and Bourlès et al. (1999). Particular attention is given to those areas where SMW cores are observed between the 24.5 and 26.25 isopycnals. Three distinct signatures are found in late winter (Fig. 2a-c) and summer (Fig. 2d- f) seasons: (i) EAW at $2^{\circ}-4^{\circ} \mathrm{S}$ whose representative station (black full circles) is located at longitude $38.0^{\circ} \mathrm{W}$ and latitude $1.6^{\circ} \mathrm{S}$ (Fig. 2a and d); (ii) EAW-SAW transitional zone at $4^{\circ}-8^{\circ} \mathrm{S}$ whose representative station (black full circles) is located at longitude $31.5^{\circ} \mathrm{W}$ and latitude $6.5^{\circ} \mathrm{S}$ (Fig. $2 \mathrm{~b}$ and e); and (iii) SAW at latitudes higher than $8^{\circ} \mathrm{S}$ whose representative station (black full circles) is located at longitude $34.5^{\circ} \mathrm{W}$ and latitude $12.5^{\circ} \mathrm{S}$ (Fig. $2 \mathrm{c}$ and f). These figures show clearly the southern incoming of SAW brought by sSEC NBC/NBUC current system during winter vs. summer (Fig. $2 \mathrm{~b}$ vs. e and $2 \mathrm{c}$ vs. f).

\subsection{Latitudinal analysis of the vertical stratification}

Vertical distributions of salinity and temperature along the easternmost boundary hydrographic stations (Fig. 1) are presented in Fig. 3. The vertical sections of salinity indicate a salinity maximum at a depth of around $120 \mathrm{~m}$ - a signature of subtropical underwaters that is due to the presence of SAW. Salinity maximum cores vary seasonally around the 24.5 isopycnal. In the late austral winter of 1995, low latitude $\left(\leq 6^{\circ} \mathrm{S}\right)$ salty surface waters were observed, except for a single surface point around $4^{\circ} \mathrm{S}$. A maximum salinity core $(\geq 36.5)$ was noticed at the thermocline level (Fig. 3a) between the latitudes of $6^{\circ} \mathrm{S}$ and $12.3^{\circ} \mathrm{S}$, and between $11^{\circ} \mathrm{S}$ and $12^{\circ} \mathrm{S}$, at the surface. The temperatures of these cores ranged from around $24^{\circ} \mathrm{C}$ to $26^{\circ} \mathrm{C}$ reaching $27^{\circ} \mathrm{C}$ in the southern stations.

During the austral summer of 1997, persistent high salinity values $(\geq 36.0)$ were found in the upper ocean layer (down to $80 \mathrm{~m}$ depth) at $2^{\circ}-10^{\circ} \mathrm{S}$ (Fig. 3b). It was combined with a shallow core of maximum salinity $(\geq 36.5)$ at the $7^{\circ}-14^{\circ} \mathrm{S}$ latitude range. In contrast to late winter, a wider area of high salinity waters was noticed at the surface layer, between $10^{\circ} \mathrm{S}$ and $14^{\circ} \mathrm{S}$ (Fig. 3b). The temperatures of the cores extended similarly to the winter period's $\left(24^{\circ} \mathrm{C}\right.$ to $\left.26^{\circ} \mathrm{C}\right)$ and southern stations attained $28^{\circ} \mathrm{C}$. The latitudes higher than $6^{\circ} \mathrm{S}$ observed for salinity maximum cores in both seasons are in accordance with the ones related to SAW signature represented by Fig. 2c and $\mathrm{f}$.

As a matter of comparison to the experimental results, interannual simulation data of salinity and temperature parameters are also presented in Fig. 3. These parameters confirm that model results of salinity and temperature (Fig. $3 \mathrm{e}-$ h) agree with REVIZEE in situ data (Fig. 3a-d) from the late winter and summer seasons. These data were obtained in scope of the Mercator Project "Transport de masse et de chaleur dans la zone de divergence du CSE dans l'Atlantique - TransAt" (2008-2009).

\subsection{Winter barrier layers}

Figures 4 through 6 present the spatial distribution of isothermal and mixed layer depths $\left(Z_{\mathrm{T}}\right.$ and $\left.Z_{\mathrm{M}}\right)$, and BL thickness (BLT), respectively, in the southwestern tropical Atlantic 

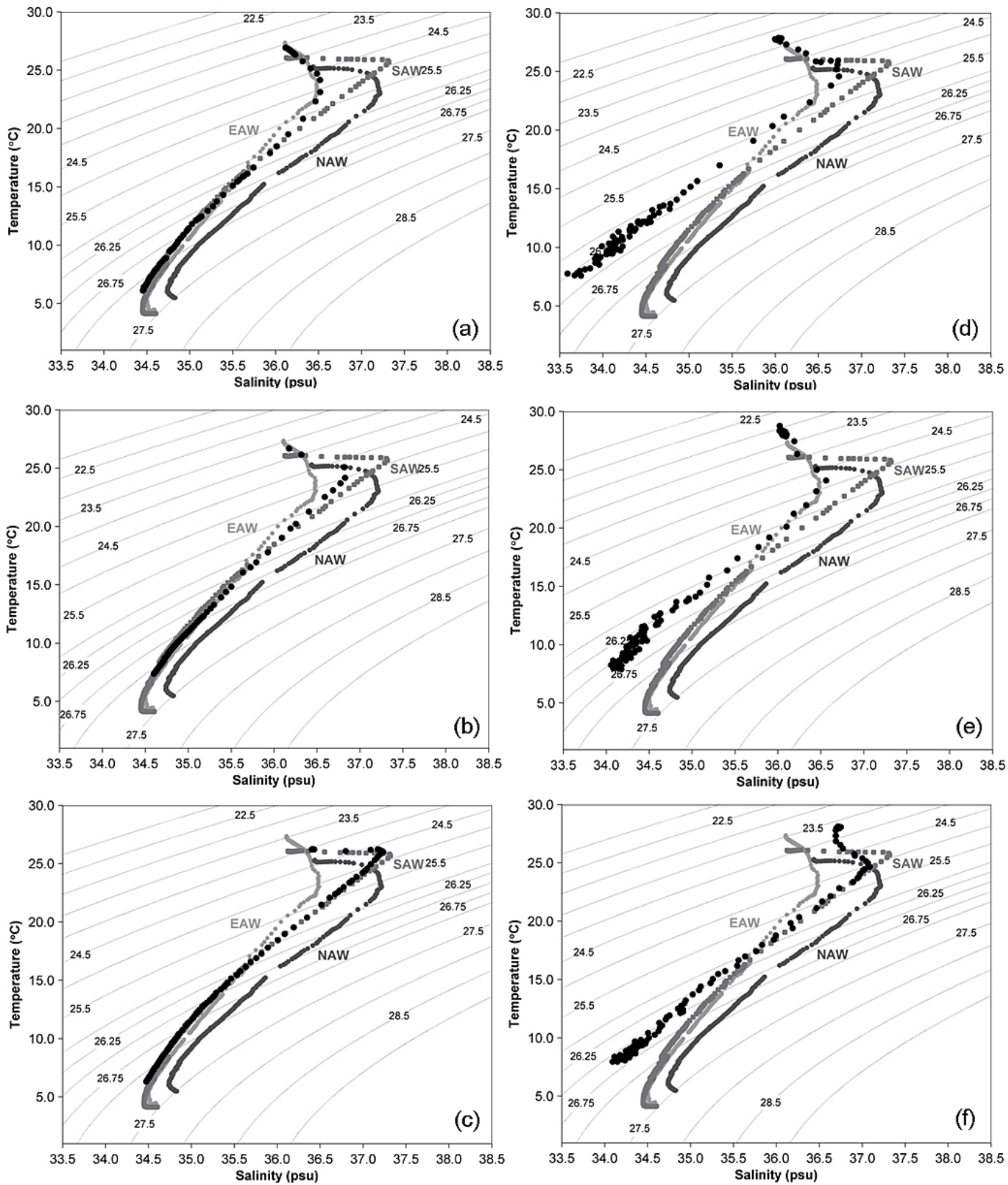

Fig. 2. Typical T/S diagrams for the easternmost REVIZEE stations located between (a, d) $2^{\circ}$ and $4^{\circ} \mathrm{S}$; (b, e) $4^{\circ}$ and $8^{\circ} \mathrm{S} ;(\mathbf{c}, \mathbf{f}) 8^{\circ}$ and $14^{\circ} \mathrm{S}$. The first column $(\mathbf{a}, \mathbf{b}, \mathbf{c})$ refers to the winter and the second one $(\mathbf{d}, \mathbf{e}, \mathbf{f})$ to the summer. Each diagram has a representative station shown as black full circles. 

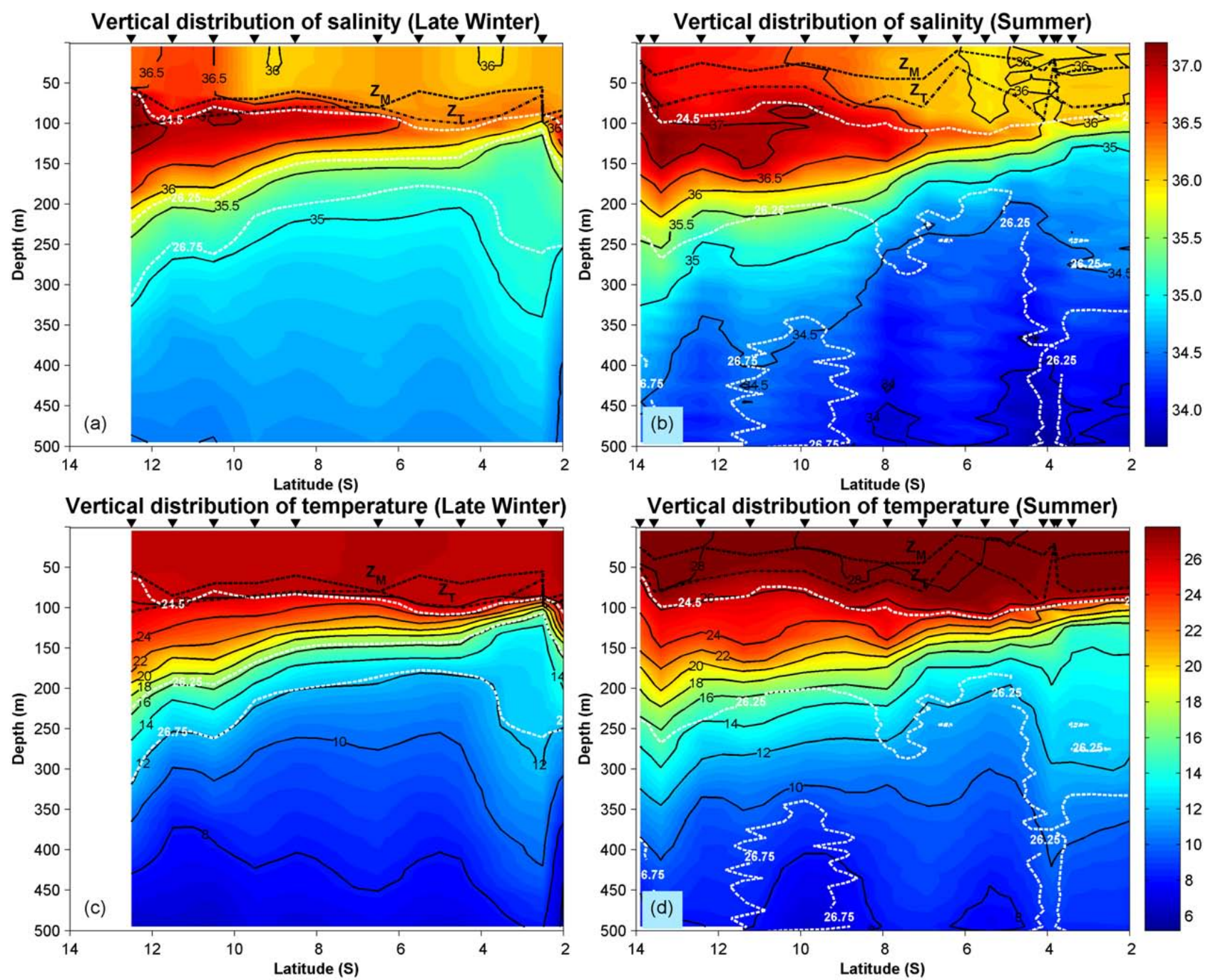

Fig. 3. Vertical salinity and temperature distributions (surface to $500 \mathrm{~m}$ depth) along the transect, indicated by a dashed line (see Fig. 1), during REVIZEE cruises. Salinity parameter during: (a) late austral winter (August-October 1995); and (b) austral summer (January-April 1997). Temperature parameter during: (c) late austral winter (August-October 1995); and (d) austral summer (January-April 1997). The black dashed lines indicate depth of isothermal and mixed layers $\left(Z_{\mathrm{T}}\right.$ and $\left.Z_{\mathrm{M}}\right)$. Dashed white lines indicate depth of $\sigma_{\theta}=24.5,26.25,26.75$ and 27.70. The location of the CTD casts is shown by the black inverted triangles. Similar Mercator results are presented from (e) to (h), following the same parameters and seasons from the REVIZEE cruises.

during late austral winter (August-October 1995) and summer (January-April 1997).

Isothermal layers during winter presented a median value of $90 \mathrm{~m}(15-135 \mathrm{~m})$, with local depths of $110 \mathrm{~m}$. $Z_{M}$ presented a median value of $70 \mathrm{~m}$ reaching $135 \mathrm{~m}$ locally. Along this period, a BLT of 5-90 $\mathrm{m}$ (median = $15 \mathrm{~m}$ ) was observed (for BLT $\geq 5 \mathrm{~m}$ ) at $83.5 \%$ of the CTD stations.

High $Z_{\mathrm{T}}$ values, limited by the $90 \mathrm{~m}$ depth isoline, were detected in two offshore subregions in the study domain: (i) at N-NE from $2^{\circ}-5^{\circ} \mathrm{S}$, and (ii) at S-SE from $7^{\circ}-12.3^{\circ} \mathrm{S}$ (Fig. 4a). A thick mixed layer (70-80 m) was also seen offshore, between $2^{\circ}$ and $10^{\circ} \mathrm{S}$ (Fig. 5a). This resulted in a thin barrier layer widely observed over the study area north of $8^{\circ} \mathrm{S}$ (Fig. 6a). However, a thick BL prevailed south of $8^{\circ} \mathrm{S}$, as a result of the combination between a deep isothermal layer (Fig. 4a) and a salt-induced (Fig. 5a) shallow mixed layer during late winter.

Southeastern trade winds are more intense during late winter, and surface salinity values low, because of the InterTropical Convergence Zone (ITCZ) precipitations at the equator. Meanwhile, subsurface salinity values are relatively high due to the presence of NBUC, whose equatorward transport increases during this period, as stated by Rodrigues et al. (2007) and Silva et al. (2009). For that reason, isothermal layer deepens and low surface salinity values induce shallow mixed layer resulting in thick BLs in the southern study 

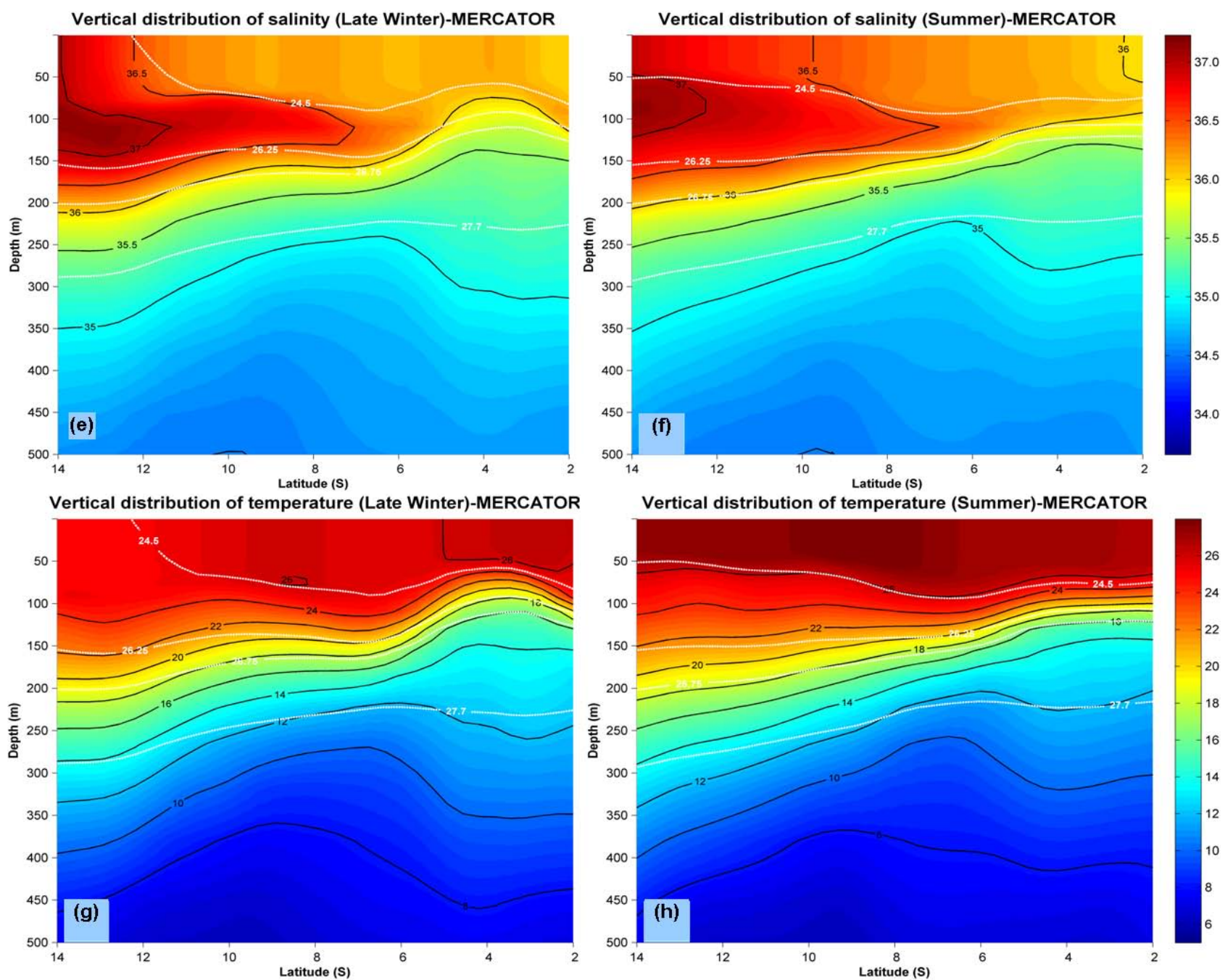

Fig. 3. Continued.

area (south of $8^{\circ} \mathrm{S}$ ). Such results are partially in agreement with Sato et al. (2006), which observed that thick BLs in the subtropical gyres occur almost exclusively in the winter hemisphere during July-September, comprising latitudes from $15^{\circ}$ to $5^{\circ} \mathrm{S}$ and longitudes from $40^{\circ} \mathrm{W}$ to $0^{\circ}$ in the South Atlantic.

\subsection{Summer barrier layers}

Isothermal layers during summer were thinner than during winter. The former showed a median value of $65 \mathrm{~m}$, ranging from 5 to $105 \mathrm{~m}$. Furthermore, shallower $Z_{\mathrm{M}}(5-50 \mathrm{~m})$ were observed, with a median value of $30 \mathrm{~m}$. The BLT differed from that in late winter, showing a lower range of 5$70 \mathrm{~m}($ median $=35 \mathrm{~m})-$ the highest frequency of occurrence, at $91.0 \%$ of the CTD stations. When compared to the winter period, the highest median of BLT (obtained within the lowest BLT range) was justified by the highest frequency of occurrence during this summer period, with $7.5 \%$ more CTD stations than during the other season.

A qualitatively similar distribution of winter isothermal layer depth can be found during the austral summer (January-April 1997). High $Z_{\mathrm{T}}$ values, limited by the $60 \mathrm{~m}$ contour, were observed in the $\mathrm{N}\left(1^{\circ}-3^{\circ} \mathrm{S} ; 37^{\circ}-42^{\circ} \mathrm{W}\right)$ to $\mathrm{NE}\left(4^{\circ}-9^{\circ} \mathrm{S} ; 32^{\circ}-35^{\circ} \mathrm{W}\right)$ subareas, and from $9^{\circ}$ to $14^{\circ} \mathrm{S}$ (Fig. 4b). The difference between the late winter and summer periods relies on computed values of mixed layer depths from the latter, with $Z_{\mathrm{M}}$ not exceeding $50 \mathrm{~m}$. These shallow mixed layers are due to the near-surface intrusion of salty SAW (Fig. 3b), which is transported westward from subtropical regions by the intensified SEC flow verified during this period (Rodrigues et al., 2007; Silva et al., 2009). Consequently, high BLT values during austral summer are not only concentrated in the southernmost part of the study area, as observed during late winter (Fig. 6a), but are also present from $1^{\circ}$ to $10^{\circ} \mathrm{S}$ (Fig. 6b). 


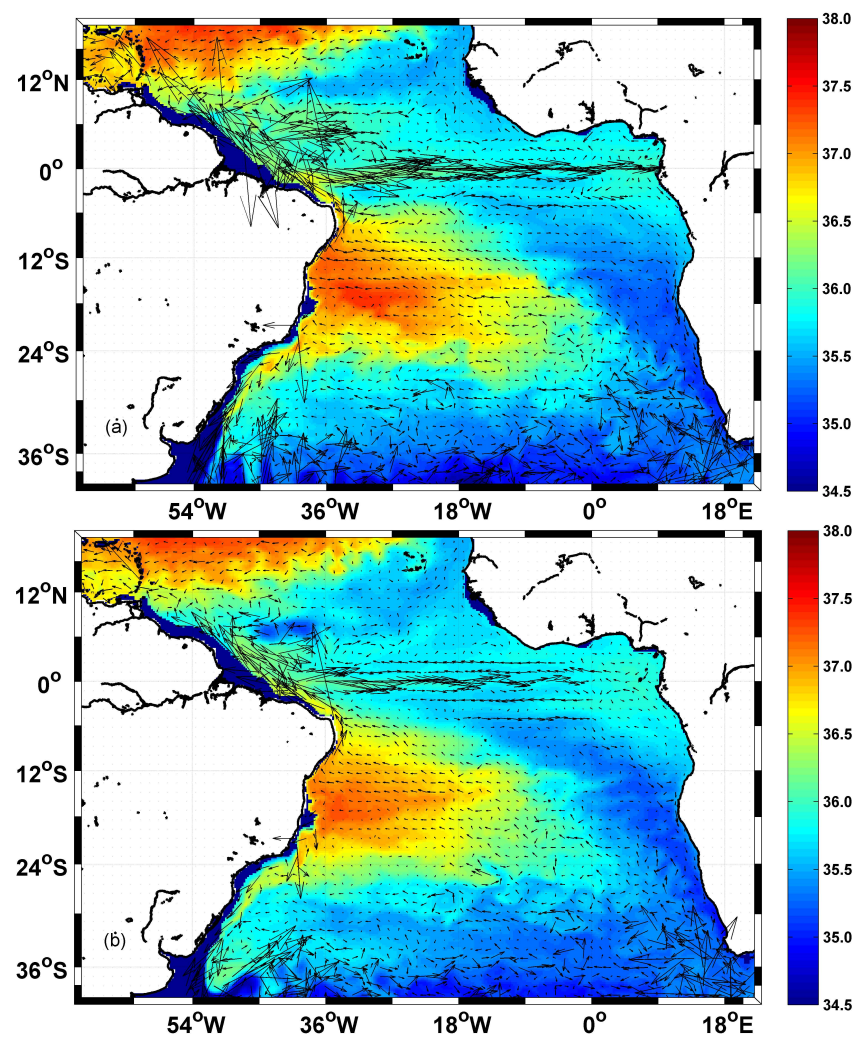

Fig. 4. Spatial distribution of isothermal layer depth $\left(Z_{\mathrm{T}}\right)$ during: (a) late austral winter (August-October 1995); and (b) austral summer (January-April 1997).

The BLs found by Mignot et al. (2007), equatorward of the subtropical gyre, might be the same ones found in this study. However, it is not possible to confirm it due to the different BL formulation criteria used in each study. De Boyer Montégut et al. (2007) and Mignot et al. (2007) defined the BLT as the difference of two depths: one whose temperature has decreased by $0.2^{\circ} \mathrm{C}$ (reference depth of $10 \mathrm{~m}$ ); and one whose potential density has increased from the reference depth by a density threshold equivalent to the same temperature change $0.2^{\circ} \mathrm{C}$ at constant salinity. In the current study it was considered that the $0.5^{\circ} \mathrm{C}$ criterion for the isothermal layer and its equivalent in density for defining the base of the BL (Sprintall and Tomczak, 1992; Tanguy et al., 2010).

\subsection{Westward transport of salty subtropical waters}

Salinity cores observed to the south of $6^{\circ} \mathrm{S}$ (Fig. 3), during both seasons, are associated with the SEC penetrating into the region from the south. They are also associated with the westward transport of SAW formed in the South Atlantic subtropical gyre (Bourlès et al., 1999; Rodrigues et al., 2007; Silva et al., 2009). Specifically, this salinity maximum water must be transported to the study area, first by the sSEC, and near the coast by the NBC/NBUC system (Stramma et al.,
1995, 2005; Pailler et al., 1999). This system carries salty and warm waters toward the equator (Fig. 7). According to this figure, the subsurface salty layer in western Atlantic was more pronounced during late austral winter (Fig. 7a) than summer (Fig. 7b). Table 1 presents the main contribution from horizontal transport up to $200 \mathrm{~m}$ and surface salinity budget for both seasons from model output (Fig. 7). Results indicate a horizontal transport 100-fold greater than the surface budget. Thus, the increased thickness of the BL appears more influenced by horizontal advection of salt than the surface freshwater balance. This conclusion was also obtained by Silva et al. (2005) for the northern area of Brazil as well as by Zeng et al. (2009) at the southeast of Vietnam.

The differences between summer and winter BLTs are displayed in Fig. 8. According to that figure, the winter BLT (solid lines) is outstanding in the southern region of the Northeastern Brazil due to deep $Z_{\mathrm{T}}$. The overcoming summer BLT is clearly noticeable mainly in the northern and central regions (thin dashed lines) of the study area. Thicker summer BLT areas are also observed between $0.5^{\circ}-3^{\circ} \mathrm{S}$ and $4^{\circ}-6^{\circ} \mathrm{S}$ due to the shallow $Z_{\mathrm{M}}$ during this season.

As observed by Rodrigues et al. (2007) and Silva et al. (2009), sSEC bifurcation occurs at lower latitudes during the summer, and maximum NBUC transport happens at $6^{\circ} \mathrm{S}$, which brings it within the SMW (see Fig. 7). In this period, evaporation overcomes precipitation, causing saltier waters at the surface/subsurface layers. In addition, northeasterly winds are present once ITCZ moves southward. Consequently, $Z_{\mathrm{T}}$ and $Z_{\mathrm{M}}$ become shallower, and the presence of SMW in the NBUC leads to the occurrence of BLs with an equal spatial distribution. This horizontal homogeneity found during the summer period suggests that the South Atlantic western boundary current has a strong influence. This was not observed by other authors (Sato et al., 2006; De Boyer Montégut et al., 2007; Mignot et al., 2007) due to the wide grid used in their study, its goal being the measurement of BLT around the global oceans.

\section{Summary and conclusion}

Global climate is strongly linked to upper tropical Atlantic dynamics and their exchange with the atmosphere. Thus, its forecasting tends to improve with an increased understanding of the processes that govern the relative distribution of the ocean's thermodynamic properties. This paper has focused on the isolation of warm surface waters from cool deep waters, by salinity-induced, mixed and barrier layers in the southwestern tropical Atlantic $\left(0^{\circ} 30^{\prime} \mathrm{N}-14^{\circ} 00^{\prime} \mathrm{S}\right.$; $\left.31^{\circ} 24^{\prime}-41^{\circ} 48^{\prime} \mathrm{W}\right)$. Thicker barrier layers (BL), higher than $60 \mathrm{~m}$ depth, were noticed in the southernmost offshore portion of the area of study during late austral winter. During the austral summer, shallower depths of isothermal and mixed layers occurred, when compared to the late winter; however, barrier layer thickness $(\mathrm{BLT}) \geq 30 \mathrm{~m}$ was observed over the 

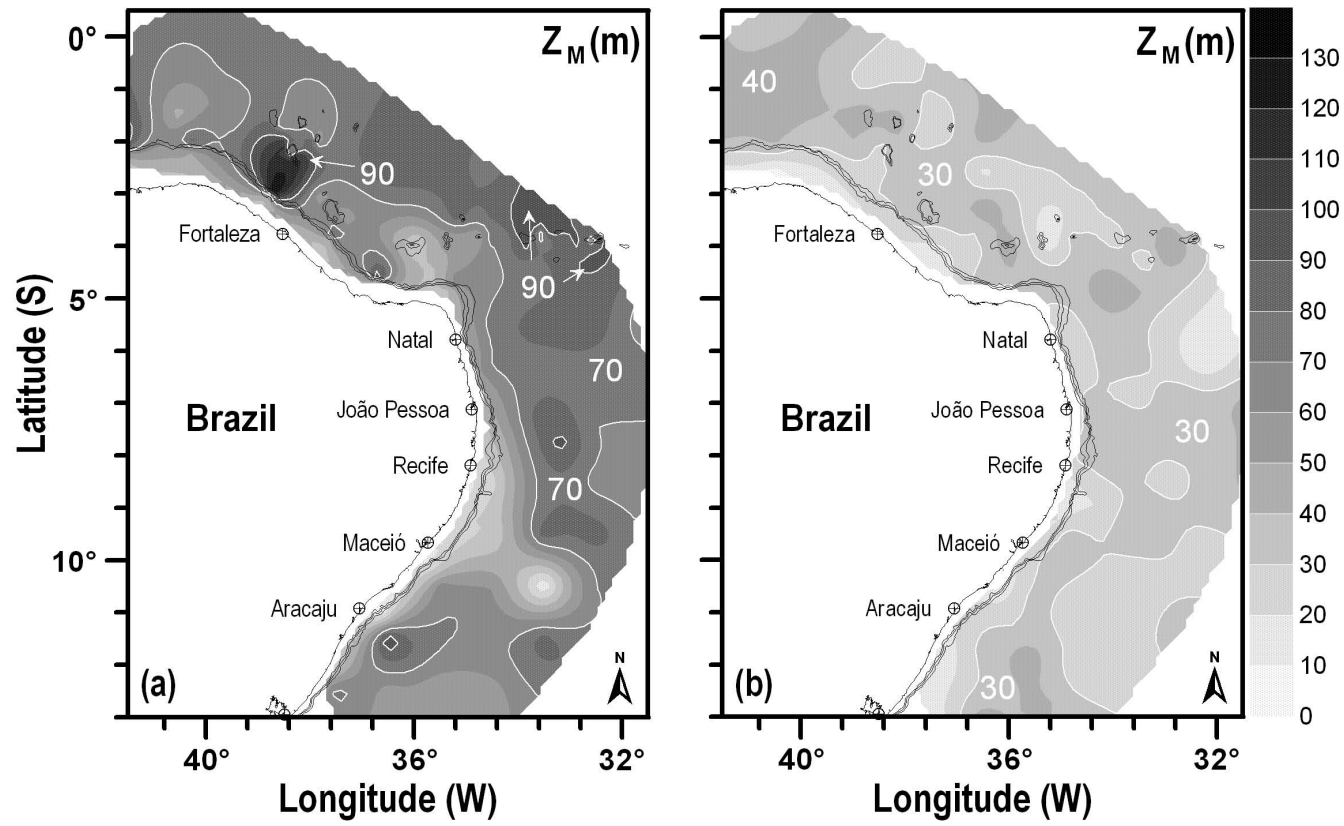

Fig. 5. Spatial distribution of mixed layer depth $\left(Z_{M}\right)$ during: (a) late austral winter (August-October 1995); and (b) austral summer (January-April 1997).
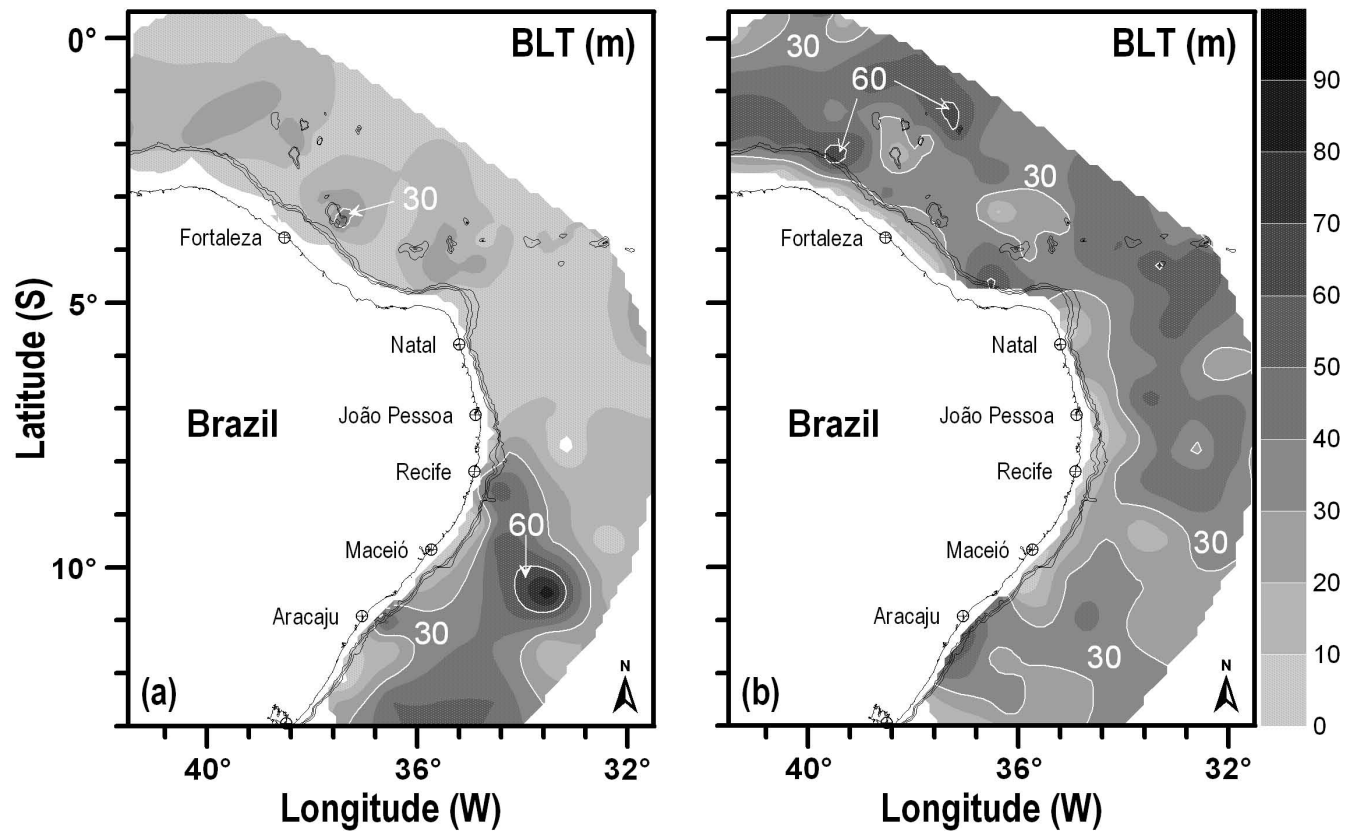

Fig. 6. Spatial distribution of barrier layer thickness (BLT) during: (a) late austral winter (August-October 1995); and (b) austral summer (January-April 1997).

entire region. In both cases, the formation of the BL seems to be associated with the advection of Salinity Maximum Waters formed in the region of the subtropical gyre. This salty water is transported to the study area by both the sSEC and the western boundary current found in the NBC/NBUC system (Stramma et al., 2005). The predominance of larger BLT in the south (north) during late winter (summer) indicates that it is associated with the southward (northward) position of sSEC (Figs. 3, 7 and 8).

Historically, it was thought that the halocline significance in the surface layer was only meaningful when dealing with higher latitude regions. However, our results suggest that 

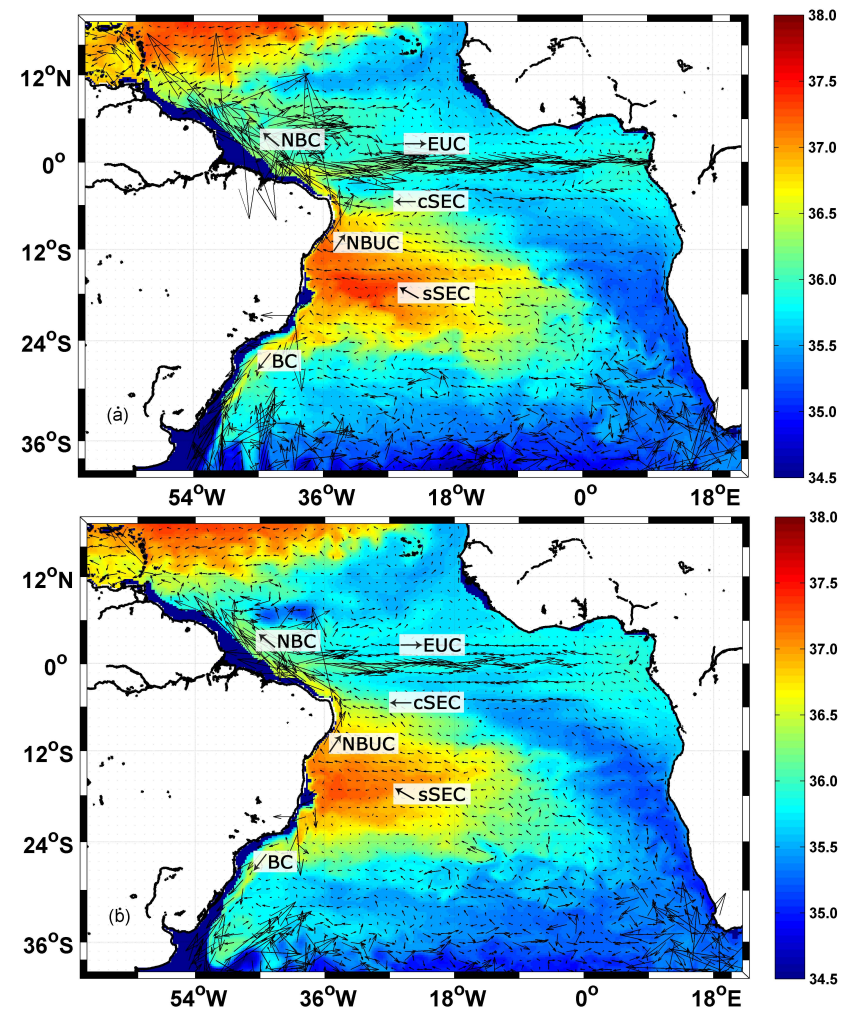

Fig. 7. Horizontal salinity distribution at $110 \mathrm{~m}$ from MercatorCoriolis modeling product during: (a) September 1995; and (b) February 1997. Vectors indicate horizontal transport direction: $\mathrm{NBC}=$ North Brazil Current; $\mathrm{EUC}=$ Equatorial Undercurrent; $\mathrm{NBUC}=$ North Brazil Undercurrent; $\mathrm{c} / \mathrm{sSEC}=$ central/southern branch of the South Equatorial Current; BC= Brazil Current.

Table 1. Horizontal transport up to $200 \mathrm{~m}$ of main salinity sources along the easternmost boundary of the REVIZEE observed area and the surface budget at this area $(\mathrm{Sv})$.

\begin{tabular}{lll}
\hline & $\begin{array}{l}\text { Winter } \\
\text { (September 1995) }\end{array}$ & $\begin{array}{l}\text { Summer } \\
\text { (February 1997) }\end{array}$ \\
\hline sSEC & +7.2 & +6.5 \\
cSEC & +18.6 & +10.5 \\
Surface Budget* & -0.05 & -0.02 \\
\hline
\end{tabular}

* Surface budget of fresh water refers to the spatial integration at REVIZEE observed area.

the inclusion of salinity dynamics and its variability are also necessary for studying mixed and BL layer behaviors in the southwestern tropical Atlantic. This variability is mostly driven by horizontal advection/vertical diffusion terms, as well as the westward transport of these salty, subducted waters by the sSEC. Therefore, the BL genesis in the southwestern tropical Atlantic needs further assessment. The contribution of each mechanism that controls the thickness of the BL should be scrutinized. These scientific tasks can only

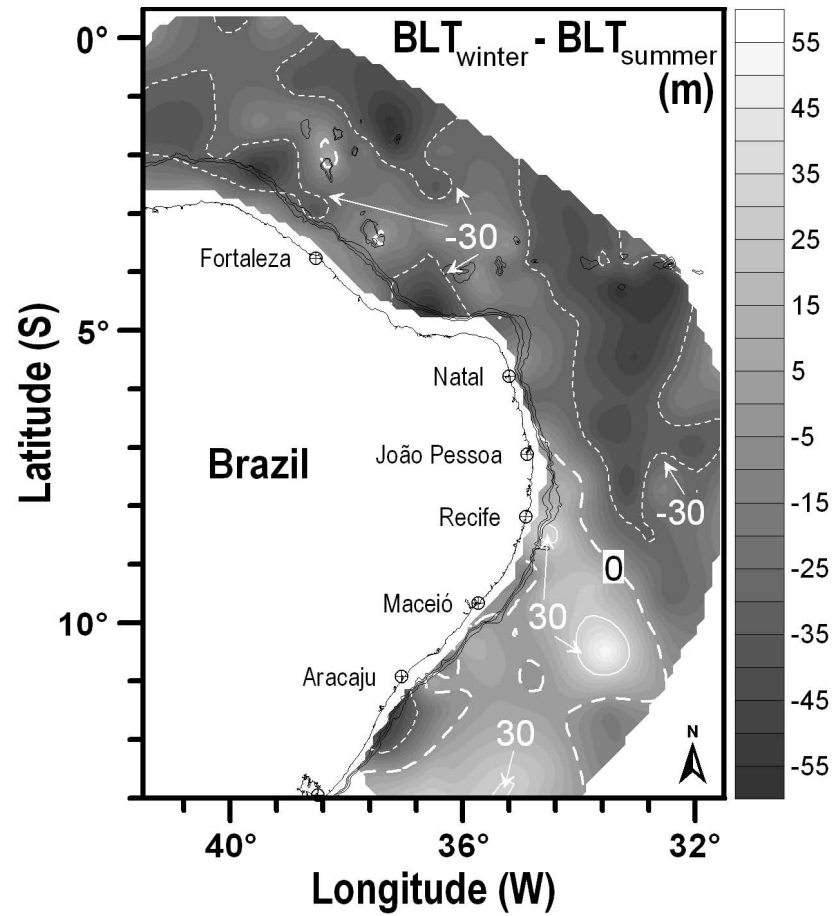

Fig. 8. Spatial distribution of the barrier layer thickness (BLT) difference between late austral winter (August-October 1995) and austral summer (January-April 1997). Thin solid (dashed) lines represent positive (negative) values. Large dashed lines represent null values.

be achieved through the acquisition of long-term time series of in situ data (e.g., temperature, salinity and current velocity). These data are derived from mooring arrays and Argo floaters deployed at key sites along the western tropical Atlantic, combined with numerical modeling efforts.

Acknowledgements. We grateful to the scientific and crew members of the R/V Antares of the Brazilian Navy for their effort and dedication during the REVIZEE Program. This work was carried out under the CNPq-IRD Project, "Climate of the Tropical Atlantic and Impacts on the Northeast" (CATIN), Process 492690/2004-9. The authors would like to thank the Brazilian National Council of Scientific and Technological Development - CNPq under the scope of the Projects BIO-NE (grant 558143/2009-1) and BACANA (grant 478398/2006-9). D. V. also wishes to thank the financial support from the Pernambuco State Agency - FACEPE (BFP-0044-1.08/08).

Edited by: E. J. M. Delhez

\section{References}

Ando, K. and McPhaden, M. J.: Variability of surface layer hydrography in the tropical Pacific Ocean, J. Geophys. Res., 102, 23063-23078, 1997. 
Blanck, H. F.: Using TOPEX Satellite El-Niño altimetry data to introduce thermal expansion and heat capacity concepts in chemistry courses, J. Chem. Educ., 76, 1635-1646, 1999.

Bourlès, B., Gouriou, Y., and Chuchla, R.: On the circulation in the upper layer of the western equatorial Atlantic, J. Geophys. Res., 104, 21151-21170, 1999.

Brainerd, K. E. and Gregg, M. C.: Surface mixed and mixing layer depths, Deep-Sea Res. Pt. I, 42, 1521-1543, 1995.

Cronin, M. F. and McPhaden, M. J.: Barrier layer formation during westerly wind bursts, J. Geophys. Res., 107(C12), 2101-2112, 2002.

De Boyer Montégut, C., Madec, G., Fischer, A. S., Lazar, A., and Iudicone, D.: Mixed layer depth over the global ocean: An examination of profile data and a profile-based climatology, J. Geophys. Res., 109, C12003, doi:10.1029/2004JC002378, 2004.

De Boyer Montégut, C. B., Mignot, J., Lazar, A., and Cravatte, S.: Control of salinity on the mixed layer depth in the world ocean: 1. General description, J. Geophys. Res., 112, C06011, doi:10.1029/2006JC003953, 2007.

Defant, A.: Schichtung und Zirkulation des Atlantischen Ozeans, Die Troposphäre, Wiss. Ergebn. Dt. Atlant. Exped. "Meteor" 1925-1927, 6, 289-411, 1936.

Defant, A.: Physical oceanography, vol. I, Pergamon Press, New York, 729 pp., 1961.

Delcroix, T. and McPhaden, M.: Interannual sea surface salinity and temperature changes in the western Pacific warm pool during 1992-2000, J. Geophys. Res., 107(C12), 8002, doi:10.1029/2001JC000862, 2002.

Dengler, M., Schott, F. A., Eden, C., Brandt, P., Fischer, J., and Zantopp, R. J.: Break-up of the Atlantic deep western boundary current into eddies at $8^{\circ} \mathrm{S}$, Nature, 432, 1018-1020, 2004.

Foltz, G. R. and McPhaden, M. J.: Impact of barrier layer thickness on SST in the central tropical North Atlantic, J. Climate, 22, 285299, 2009.

Goes, M., Molinari, R., da Silveira, I., and Wainer, I.: Retroflection of the North Brazil Current during February 2002, Deep-Sea Res., 52, 647-667, 2005.

Kara, A. B., Rochford, P. A., and Hurlburt, H. E.: Mixed layer depth variability and barrier layer formation over the north $\mathrm{Pa}-$ cific ocean, J. Geophys. Res., 105, 16783-16801, 2000.

Lambert, R. B. and Sturges, W.: A thermohaline staircase and vertical mixing in the thermocline, Deep-Sea Res., 24, 211-222, 1977.

Levitus, S.: Climatological atlas of the World Ocean, NOAA Prof. Paper 13, U.S. Govt. Printing Office, 173 pp., 1982.

Lukas, R. and Lindström, E.: The mixed layer of the western equatorial Pacific ocean, J. Geophys. Res., 96, 3343-3357 (Suppl.), 1991.

Lumpkin, R. and Garzoli, S. L.: Near-surface circulation in the tropical Atlantic ocean, Deep-Sea Res., 52, 495-518, 2005.

Medeiros, C., Araujo, M., Freitas, I., and Rollnic, M.: Massa d'água da região oeste do Atlântico tropical, in: Programa REVIZEE SCORE NE, vol. 1, edited by: Hazin, F., 56-69, 2009a.

Medeiros, C., Araujo, M., Rollnic, M., and Freitas, I.: Estrutura termohalina da região oeste do Atlântico tropical, in: Programa REVIZEE - SCORE NE, vol. 1, edited by: Hazin, F., 40-55, 2009b.

Mignot, J., de Boyer Montégut, C. B., Lazar, A., and Cravatte, S.: Control of salinity on the mixed layer depth in the world ocean: 2. Tropical areas, J. Geophys. Res., 112, C06011, doi:10.1029/2006JC003954, 2007.

Monterrey, G. and Levitus, S.: Seasonal variability of mixed layer depth for the world ocean, NOAA Atlas NESDIS 14, U.S. Department of Commerce, Washington, D.C., 96 pp., 1997.

Ohlmann, J. C., Siegel, D. A., and Gautier, C.: Ocean mixed layer depth heating and solar penetration: A global analysis, J. Climate, 9, 2265-2280, 1996.

Pailler, K., Bourlès, B., and Gouriou, Y.: The barrier layer in the western Atlantic ocean, Geophys. Res. Lett., 26, 2069-2072, 1999.

Rodrigues, R. R., Rothstein, L. M., and Wimbush, M.: Seasonal variability of the South Equatorial Current bifurcation in the Atlantic ocean: A numerical study, J. Phys. Oceanogr., 37, 16-30, 2007.

Sato, K., Suga, T., and Hanawa, K.: Barrier layers in the subtropical gyres of the world's oceans, Geophys. Res. Lett., 33, L08603, doi:10.1029/2005GL025631, 2006.

Schott, F. A., Dengler, M., Zantropp, R., Stramma, L., Fischer, J., and Brandt, P.: The shallow and deep western boundary circulation of the South Atlantic at $5^{\circ}-11^{\circ} \mathrm{S}$, J. Phys. Oceanogr., 35, 2031-2053, 2005.

Silva, A. C., Araujo, M., Medeiros, C., Silva, M., and Bourlès, B.: Seasonal changes in the mixed and barrier layers in the western equatorial Atlantic, Braz. J. Oceanogr., 53(3/4), 83-98, 2005.

Silva, M. A., Araujo, M., Servain, J., Peven, P., and Lentini, C. A. D.: High-Resolution Regional Ocean Dynamics Simulation in the Southwestern Tropical Atlantic, Ocean Model., 30, 256-269, 2009.

Spall, M. A.: A diagnostic study of wind- and buoyancy-driven north Atlantic circulation, J. Geophys. Res., 96, 18509-18518, 1991.

Sprintall, J. and Tomczak, M.: Evidences of the barrier layer in the surface layer of the tropics, J. Geophys. Res., 97, 7305-7316, 1992.

Stramma, L. and Schott, F.: The mean flow field of the tropical Atlantic ocean, Deep-Sea Res., 46B, 279-303, 1999.

Stramma, L., Fischer, J., and Reppin, J.: The North Brazil Undercurrent, Deep-Sea Res. Pt. I, 42, 773-795, 1995.

Stramma, L., Rhein, M., Brandt, P., Dengler, M., Boning, C., and Walter, M.: Upper ocean circulation in the western tropical Atlantic in boreal fall 2000, Deep-Sea Res. Pt. I, 52, 221-240, 2005.

Swenson, M. S. and Hansen, D. V.: Tropical Pacific Ocean mixed layer heat budget: The Pacific cold tongue, J. Phys. Oceanogr., 29, 69-81, 1999.

Tanguy, Y., Arnault, S., and Lattes, P.: Isothemal, mixed, and barrier layers in the subtropical and tropical Atlantic Ocean during the ARAMIS experiment, Deep-Sea Res. Pt. I, 57, 501-517, 2010.

Vialard, J. and Delecluse, P.: An OGCM study for TOGA decade. Part II: Barrier layer formation and variability, J. Phys. Oceanogr., 28, 1089-1106, 1998.

Wilson, W. D., Johns, E., and Molinari, R. L.: Upper layer circulation in the western tropical North Atlantic Ocean during August 1989, J. Geophys. Res., 99, 22513-22523, 1994.

Zeng, L., Du, Y., Xie, S.-P., and Wang, D.: Barrier Layer in the South China Sea during summer 2000, Dynam. Atmos. Oceans, 47, 38-54, 2009. 